\title{
Two Case Reports of Life-Threatening Ethanol-Induced Anaphylaxis
}

\author{
S.L. Fernando ${ }^{a, c, d} \quad$ L.R. Clarke ${ }^{b}$ \\ Departments of aAllergy and ${ }^{\mathrm{b}}$ Dietetics, Royal North Shore Hospital, \\ 'Northern Clinical School, University of Sydney, and dPaLMS \\ Immunorheumatology Laboratory, Sydney, N.S.W., Australia
}

\section{Key Words}

Alcohol · Ethanol · Allergy · Anaphylaxis

\begin{abstract}
Adverse reactions to alcoholic beverages are common and diverse in aetiology. Ethanolinduced anaphylaxis, however, is a rare but often life-threatening condition that warrants careful evaluation in suspected individuals. We present the cases of two patients who developed urticaria, angioedema and throat constriction within minutes of consuming white wine. Both individuals demonstrated no adverse reaction to doubleblind placebo-controlled challenges to metabisulphite or sodium salicylate. However, an open challenge to white wine elicited urticaria in both subjects. This reaction was reproduced with a double-blind placebo-controlled challenge to ethanol and was accompanied by a rise in serum total tryptase levels. Positive skin test responses to $2 \%$ acetic acid, a breakdown product of ethanol, were elicited from both patients but not from three normal controls. These two cases demonstrate the need for a systematic approach for the evaluation of allergic reactions to alcohol.
\end{abstract}

\section{Background}

Adverse reactions to alcoholic beverages are common and diverse in aetiology [1]. Ethanol-induced anaphylaxis is, however, uncommon [2]. We report two cases of lifethreatening reactions characterised by generalised urticaria, facial swelling, throat constriction and hypotension after the consumption of white wine. In both cases, an IgEmediated response to acetic acid, a breakdown product of ethanol, was found to be the underlying cause of these reactions. 


\begin{tabular}{l|l|l|l} 
Case Reports in & $\begin{array}{l}\text { Case Rep Dermatol 2009;1:1-6 } \\
\text { D01: } 10.1159 / 000209154\end{array}$ & Published online: April 29, 2009 & $\begin{array}{l}\text { @ 2009 S. Karger AG, Basel } \\
\text { ISSN 1662-6567 } \\
\text { www.karger.com/cde }\end{array}$ \\
\hline
\end{tabular}

\section{Case Reports}

\section{Case 1}

A 58-year-old female reported three separate adverse reactions to meals comprised of seafood and white wine. The first episode occurred after ingestion of shellfish and consumption of $10 \mathrm{ml}$ of white wine $(12 \%$ ethanol v/v). Within a few minutes, she developed generalised urticaria, throat itch and dizziness. Her symptoms resolved promptly after taking $10 \mathrm{mg}$ cetirizine. The second episode occurred within minutes of the simultaneous consumption of crab soup and $5 \mathrm{ml}$ of white wine (14\% ethanol $\mathrm{v} / \mathrm{v})$. She developed urticaria over her palms without any accompanying cardiorespiratory symptoms. Her third and most severe episode occurred whilst ingesting a fish cocktail and consuming $10 \mathrm{ml}$ of white wine $(12 \%$ ethanol $\mathrm{v} / \mathrm{v})$. The reaction was characterised by generalised urticaria, angioedema of the lips and tongue, throat constriction, and change in voice. Self-administered antihistamines were ineffective in ameliorating her symptoms and she subsequently collapsed, and an ambulance was promptly summoned. Her blood pressure was initially unrecordable and she was immediately administered $300 \mu \mathrm{g}$ adrenaline intramuscularly, following which she regained consciousness with her systolic blood pressure measured at $120 \mathrm{~mm} \mathrm{Hg}$. She had a history of hypertension that was treated with $150 \mathrm{mg}$ irbesartan daily and supraventricular tachycardia that was controlled with $240 \mathrm{mg}$ verapamil daily.

This patient was initially evaluated with skin-prick testing, which demonstrated no response to either fresh grapes or an extensive range of seafood. Double-blind placebo-controlled challenges to metabisulphite and salicylate, chemicals contained in white wine, were tolerated without any adverse reactions. An open incremental challenge to Chardonnay ( $12 \%$ ethanol v/v) elicited urticaria after the cumulative ingestion of $4 \mathrm{ml}$. On a separate occasion, she developed urticaria after consumption of 0.4 $\mathrm{ml}$ of $96 \%$ ethanol. A double-blind placebo-controlled challenge containing either $20 \mathrm{ml}$ of $96 \%$ ethanol in $300 \mathrm{ml}$ of sweetened grape juice or sweetened grape juice alone [3] resulted in generalised urticaria after $7 \mathrm{ml}$ of the ethanol mixture was consumed. This reaction was accompanied by a rise in serum total tryptase from a non-detectable level at baseline to $13.5 \mathrm{ng} / \mathrm{ml} 1 \mathrm{~h}$ after the onset of symptoms. The patient also had a positive skin-prick test response to $2 \%$ acetic acid, but no responses were elicited to varying concentrations of ethanol $(9.6,19.2,48,96 \%)$. In contrast, no response to $2 \%$ acetic acid was found in three normal controls.

The patient was placed on an alcohol-restricted diet including the avoidance of significant traces found in foods such as liqueur chocolates, marinades and tomato puree and overripe fruit [4]. An anaphylaxis management plan was formulated with an adrenaline autoinjector prescribed for use in the event of an accidental exposure resulting in a severe reaction characterised by angioedema of the tongue or the presence of cardiorespiratory symptoms. A MedicAlert ${ }^{\mathrm{TM}}$ bracelet was fashioned stipulating her alcohol allergy. She has had no further adverse events at one year following her diagnosis.

\section{Case 2}

A 22-year-old female, previously well, developed generalised urticaria and syncope after consumption of $30 \mathrm{ml}$ of sparkling white wine Chardonnay ( $12 \%$ ethanol $\mathrm{v} / \mathrm{v})$. She regained consciousness after a few minutes and ingested an antihistamine, which abrogated her rash. She did not seek emergency medical attention for her reaction and was evaluated six weeks later. A skin-prick test to fresh grapes elicited no reaction. As for the previous patient, double-blind placebo-controlled challenges to metabisulphite and salicylate demonstrated no adverse reactions. Urticaria was elicited following the cumulative ingestion of $5 \mathrm{ml}$ of Chardonnay (12\% ethanol v/v). A double-blind placebo-controlled challenge containing either $20 \mathrm{ml}$ of $96 \%$ ethanol in $300 \mathrm{ml}$ of sweetened grape juice or sweetened grape juice alone resulted in generalised urticaria after $5 \mathrm{ml}$ of the ethanol mixture was consumed. This reaction was accompanied by a rise in serum total tryptase from a non-detectable level at baseline to $14.2 \mathrm{ng} / \mathrm{ml} 1$ hour after the onset of symptoms. She had a positive skin-prick test response to $2 \%$ acetic acid but no response to varying concentrations of ethanol $(9.6,19.2,48,96 \%)$. This patient was also placed on an alcohol-restricted diet, an anaphylaxis action plan was formulated and an adrenaline autoinjector was provided. She has also remained free from any adverse reactions for one year. 


\begin{tabular}{l|l|l|l} 
Case Reports $h$ & Case Rep Dermatol 2009;1:1-6 & Published online: April 29, 2009 & $\begin{array}{l}\text { ○ 2009 S. Karger AG, Basel } \\
\text { ISSN 1662-6567 } \\
\text { www.karger.com/cde }\end{array}$ \\
\hline
\end{tabular}

\section{Discussion}

The most common cutaneous adverse reaction to alcohol is flushing. Drugs such as disulfiram, metronidazole, griseofulvin and ketoconazole, physiological states such as menopause, pathological states such as rosacea and carcinoid, and the presence of certain aldehyde dehydrogenase isoforms in Oriental races can exacerbate alcohol-induced flushing $[5,6]$. Intolerance to metabisulphites and salicylates found in wine have been incriminated in a small number of studies as a cause of episodic urticaria, rhinitis, asthma and anaphylaxis with most of these studies focusing on individuals with pre-existing asthma $[7,8]$. Metabisulphites, brewer's yeast, hops and barley contained in beer have all been implicated in episodic cutaneous eruptions and anaphylaxis $[9,10]$. More recent evidence using double-blind placebo-controlled challenges suggests that intolerance to these chemicals is directly responsible for only a relatively small number of cases of adverse reactions to wine in asthmatics $[11,12]$. IgE-mediated hypersensitivity to grape has been rarely reported as a cause of alcohol-induced anaphylaxis [13, 14]. Decreased activity of the histamine-degrading enzyme, monoamine oxidase, has been proposed in certain individuals as a mechanism of intolerance to the histamine that is contained in red wine [15]. Interestingly, oral sensitisation to Hymenoptera venom, known to contaminate the wine during its preparation, has recently been implicated as a cause of reactions in certain subjects [12].

Ethanol, itself, has only rarely been implicated in anaphylactic reactions to alcoholic drinks. As illustrated by our first case, such reactions appear to be precipitated by relatively small quantities of ethanol, and $1 \mathrm{ml}$ may be sufficient to provoke severe anaphylaxis $[1,16]$. Degranulation of mast cells occurs during such episodes as demonstrated in skin biopsies of urticarial lesions and the rise in serum histamine [17] and total tryptase levels [3]. Serial measurement of serum total tryptase is the most commonly used method of detecting and confirming anaphylaxis and is more reliable than histamine because of its stability and longer biological half-life [18]. Plasma histamine levels peak within 5-10 min of onset of symptoms and then fall to baseline levels within $60 \mathrm{~min}$ [19]. Serum tryptase is detected 60-90 min after the onset of anaphylaxis and persists for up to $5 \mathrm{~h}[20]$. As shown in both our study and that of Emonet et al. [3], serum total tryptase increased following the development of symptoms after an ethanol challenge. It must be noted, however, that elevated serum total tryptase levels are uncommonly found in food-related anaphylaxis for reasons which are not fully understood [21]. Hence, caution should be exercised and further studies are needed to determine the value of tryptase determination in ethanol-related anaphylaxis.

Anaphylactic reactions to ethanol appear to be IgE-mediated responses to acetic acid, a breakdown product of the ethanol metabolism, rather than to ethanol itself; and positive skin-test responses can be demonstrated in such individuals to acetic acid, whereas responses to ethanol are invariably negative $[22,23]$. Non-IgE-mediated intolerance to ethanol and/or its metabolites remains a possibility in other individuals with negative skin responses to grape, ethanol, acetaldehyde and acetic acid and negative double-blind placebo-controlled challenges to metabisulphite and salicylate. Upon investigation, these individuals may only demonstrate a reaction following an oral exposure to ethanol [24]. It is pertinent to note that food chemicals such as metabisulphites and salicylates, and grapes are absent in gin, vodka and whisky [25], and this may heighten the speculation that ethanol is the inciting factor in patients who develop an urticarial or anaphylactic reaction to these spirits if consumed neat. 
In conclusion, we propose that once flushing reactions are excluded on history taking, a stepwise approach should be adopted for the evaluation of adverse reactions to alcoholic beverages. The patient can initially be investigated with skin-prick tests against foods that were simultaneously consumed with the alcoholic beverage or against fresh green and red grapes. If negative, double-blind placebo-controlled challenges to metabisulphite and salicylate can be performed; and if then necessary, a double-blind placebo-controlled challenge to ethanol. Those subjects that develop urticaria, angioedema or cardiorespiratory symptoms upon challenge to these chemicals should have measurements of serum tryptase performed to ascertain objective evidence of mast cell degranulation. Skin test responses to ethanol metabolites may also help elucidate the underlying mechanism and identify the allergen involved. Such a strategy enables the clinician to objectively determine the alcoholic beverages and/or food substances that the patient can then restrict from their diet. Further studies using larger cohorts are also needed to better define the prevalence and role of ethanol hypersensitivity and other factors involved in mediating adverse reactions to alcoholic beverages. 


\section{References}

1 Sticherling M, Brash J, Bruning H, Christophers E: Urticarial and anaphylactoid reactions following ethanol intake. Br J Dermatol 1995;132:464-467.

2 Przybilla B, Ring J: Anaphylaxis to ethanol and sensitization to acetic acid. Lancet 1983;i:483.

-3 Emonet S, Hogendijk S, Voegeli J, Eigenmann P, Roux N, Hauser C: Ethanolinduced urticaria: elevated tryptase levels after double-blind, placebo-controlled challenge. Dermatology 1998;197:181-182.

-4 Mallon DF, Katelaris CH: Ethanol-induced anaphylaxis following ingestion of overripe rock melon, Cucumis melo. Ann Allergy Asthma Immunol 1997;78:285286.

-5 Wilkin JK: Flushing reactions: consequences and mechanisms. Ann Intern Med 1981;95:468-476.

-6 Goedde HW, Agarwal DP, Fritze G, Meier-Tackmann D, Singh S, Beckmann G, Bhatia K, Chen LZ, Fang B, Lisker R, et al: Distribution of ADH2 and ALDH2 genotypes in different populations. Hum Genet 1992;88:344-346.

7 Jamieson DM, Guill MF, Wray BB, May JR: Metabisulfite sensitivity: case report and literature review. Ann Allergy 1985;54:115-121.

-8 Wüthrich B, Huwyler T: Asthma due to disulphites. Schweiz Med Wochenschr 1989;119:1177-1184.

-9 Gall H, Boehnecke WH, Gietzen K: Intolerance to sodium metabisulfite in beer. Allergy 1996;51:516-517.

10 Fernández-Anaya S, Crespo JF, Rodriguez JR, Daroca P, Carmona E, Herraez L, López-Rubio A: Beer anaphylaxis. J Allergy Clin Immunol 1999;103:959-960.

$\checkmark 11$ Chung CH, Mirakhur B, Chan E, et al: Changes in bronchial hyperresponsiveness following high- and low-sulphite wine challenges in wine-sensitive asthmatic subjects. Clin Exp Allergy 2007;37:1062-1066.

12 Armentia A: Adverse reactions to wine: think outside the bottle. Curr Opin Allergy Clin Immunol 2008;8:266-269.

-13 Alcoceba Borràs E, Botey Faraudo E, Gaig Jané P, Bartolomé Zavala B: Alcoholinduced anaphylaxis to grapes. Allergol Immunopathol (Madr) 2007;35:159-161.

- 14 Sbornik M, Rakoski J, Mempel M, Ollert M, Ring J: IgE-mediated type-I-allergy against red wine and grapes. Allergy 2007;62:1339-1340.

15 Wantke F, Gotz M, Jarisch R: The red wine test intolerance to histamine as a model for food intolerance. Allergy Proc 1994;15:27-32.

16 Hicks R: Ethanol, a possible allergen. Ann Allergy 1968;26:641-643.

-17 Ting S, Rauls DO, Ashbaugh P, Mansfield LE: Ethanol-induced urticaria: a case report. Ann Allergy 1988;60:527-530.

18 Sampson HA, Munoz-Furlong A, Campbell RL, et al: Second symposium on the definition and management of anaphylaxis: summary report. Second National Institute of Allergy and Infectious Disease/Food Allergy and Anaphylaxis Network symposium. J Allergy Clin Immunol 2006;117:391-397.

19 Simons FER, Frew AJ, Ansotegui IJ, Bochner BS, Golden DBK, Finkelman FD, Leung DYM, Lotvall J, Marone G, Metcalfe DD, Müller U, Rosenwasser LJ, Sampson HA, Schwartz LB, van Hage M, Walls AF: Risk assessment in anaphylaxis: current and future approaches. J Allergy Clin Immunol 2007;120:S2S24.

20 LaRoche D, Vergnaud M, Sillard B, et al: Biochemical markers of anaphylactoid reactions to drugs. Comparison of plasma histamine and tryptase. Anesthesiology 1991;75:945-949.

21 Schwartz LB: Diagnostic value of tryptase in anaphylaxis and mastocytosis. Immunol Allergy Clin North Am 2006;26:451-463.

22 Boehncke WH, Gall H: Ethanol metabolite acetic acid as causative agent for type1 hypersensitivity-like reactions to alcoholic beverages. Clin Exp Allergy 1996;26:1089-1091.

23 Nakagawa Y, Sumikawa Y, Nakamura T, Itami S, Katayama I, Aoki T: Urticarial reaction caused by ethanol. Allergol Int 2006;55:411-414.

24 Ehlers I, Hipler UC, Zuberbier T, Worm M: Ethanol as a cause of hypersensitivity reactions to alcoholic beverages. Clin Exp Allergy 2002;8:1231-1235. 
25 Swain AR, Dutton SP, Truswell AS: Salicylates in foods. J Am Diet Assoc 1985;85:950-960. 